\title{
ANALISIS FAKTOR-FAKTOR PENYEBAB KREDIT MACET PADA BANK NAGARI CABANG SITEBA
}

\author{
BAIYA, JHON FERNOS \\ Akademi Keuangan dan Perbankan "Pembangunan" \\ Jhonfernos@akbpstie.ac.id
}

\begin{abstract}
Bank Nagari Siteba Branch is one of the banks that provide loans in the form of loans, the purpose of which is to help the community, especially in the neighborhood of Siteba and Padang city. In the implementation of granting loans. Bank Nagari Branch always conducts credit analysis of prospective customers. the debtor's business as well as conducting interviews with the debtor. For the security of the credit that is given to the customer, the nagari bank requires credit guarantees to the customer. rescue and settlement of bad loans by the siteba bank nagari branch can be done in various ways, either by the combination is by giving arrears and warning letters to the debtor, giving relief on interest payments and principal repayments, and urging the debtor to sell collateral. The main cause of bad credit can be from both parties, it is normal for banks to be less sharp in analyzing the background defend the prospective customer, so the intent and purpose and repayment of the credit provided cannot be clearly known. from the debtor, the low level of education of customers who receive credit, and the lack of open communication between customers and the bank, and this is the basis or cause of bad credit.
\end{abstract}

Keywords: Kredit Macet

\section{PENDAHULUAN}

Perbankan merupakan sektor terpenting dalam pembanguanan perekonomian suatu Negara .Menurut Undang-undang No.10 tahun 1998 Bank adalah badan usaha yang menghimpun dana dari masyarakat dalam bentuk simpanan dan menyalurkannya kembali dalam bentuk ktedit atau bentuk lainnya dalam rangka meningkat taraf hidup masyarakat banyak. Peranan perbankan dalam memperbaiki pertumbungan ekonomi di indonesia saling mempengaruhi, dalam industri perbankan pada saat ini, masalah yang paling banyak dihadapi adalah masalah dalam pegambilan kredit, sehingga harus mendapatkan perhatian serius.

Bagi masyarakat, kredit sangat di perlukan dalam mendukung dan mengembangkan usahanya, dimana dengan menggunakan dana kredit bisa untuk menambahkan atau meningkat berbagai faktor produksi baik berupa tambahan modal kerja,peningkatan kemampuan sumber daya manusia dan lain sebagainya. Dalam mengelola perbankan harus di lakukan secara professional sehingga dapat memperoleh keuntungan ini merupakan tujuan bank di didirikan.ada tiga kegiatan jasa bank yang perlu di kelola secara professional yaitu kegiatan menghimpum dana(funding)menyalurkan dana (lending) dan jasa-jasa lainya(service).ketiga kegiatan jasa ini harus di perhatikan secara bersamaan. karena masing-masing kegitaan ini saling berkaitan,sehingga apabila salah satu tidak di kelola secara profeional maka dapat mengakibatkan kerugian bagi bank,terutama kegiatan funding dan lending. 
Kegiatan funding merupakan upaya bank untuk menarik dana masyarakat yang berlebihan dan menawarkan produk-produk simpanan dalam bentuk giro,tabungan ,deposito,melalui kegiatan funding ini,maka bank mempunyanyi dana yang siap di jual kembali kepada masyarakat yang membutuhkan dana.

Kegiatan lending merupakan penyaluran dana yang dihimpun dalam bentuk pinjaman atau kredit.setiap penyaluran kredit oleh kreditur tentu megandung resiko,karena adanya keterbatasan kemampuan manusia dalam mempredikisi masa yang akan datang ,untuk itu bank harus merencana sedemikian rupa dan berusaha untuk menekan resiko munculnya penyebab kredit macet,dan oleh sebab itu pihak bank juga perlu menilai kelayakan usaha dari debitur dan juga di perlukan adanya pengelolaan dan pengawasan,sehingga kesenambungan usaha perbankan terjaga.

Dalam penyaluran kredit kepada masyarakat tidak keseluruhan dana yang di salurkan tersebut dapat di kembalikan seluruhnya atau sebagaimna mestinya, maka hal inilah yang menjadi penyebab-penyebab kredit macet.

Kredit macet dapat di artikan sebagai ketidaksanggupan debitur untuk melunasi pinjamannya kepada bank berupa angsuran pokok dari pinjaman beserta bunganya,serta biaya lainya dimna mengalami kegagalan karena deviasi (penyimpangan)ehingga tidak sesuai dengan pejanjian yang telah di sepakati yang akhirnya dapat membawa kerugian pada Bank Nagari Cabang Siteba.

Kredit macet timbul tidak dengan seketika, melainkan secara bertahap dimna terjadi berbagai penurunan aspek yang dimiliki debitur yang berakhir dengan ketidakmampuan debitur membayar kreditnya. Mencari penyebab kredit macet adalah sulit,karena ada banyak faktor-faktor yang mempengaruhi baik dari sifat intern maupun ekstern.faktor ekstern "berasal dari luar perusahaan "seperti keadaan ekonomi,persaingan bencana alam dan dari debitur itu sediri.sedangkan faktor intern"berasal dari dalam pihak perusahaan"seperti kesalahan penilaian dalam memberikan kredit atau minimnya pengawasan dan pembinaan terhadap kredit yang disalurkan.kredit macet disebabkan berbagai faktor yang berkaitan antara satu sama lainnya,untuk itu harus segera mungkin mendapatkan penyelesaian. karena dapat menyebabkan terganggunya kondisi bank.

Bank nagari cabang siteba dengan segala kepemilikannya memberikan fasilitas kredit kepada masyarakat. Dengan kemudahan yang ditawarkan oleh bank tidak sedikit masyarakat melakukan pengembalian yang tidak sesuai dan terkadang malah menjadi bermasalah. Berikut data kredit yang tersalurkan sesuai kegunaan pada bank nagari cabang siteba

Tabel 1.1

Tingkat Pengembalian Kredit Menurut Jenis Dan Guna Bank Nagari Cabang Siteba

Tahun 2012-2015

( Dalam Ribuan Rupiah )

\begin{tabular}{ccccc}
\hline No & Tahun & Investasi & Modal Kerja & Konsumtif \\
\hline 1 & 2012 & 619.856. & 230.283 & 376.537. \\
2 & 2013 & 559.998 & 193.623 & 277.537 \\
3 & 2014 & 411.812 & 120.488 & 214.247 \\
4 & 2015 & 304.917 & 110.247 & 234.176 \\
\hline
\end{tabular}

Sumber: Bank Nagari Cabang Siteba, 
Dari tabel 1.1 diatas dapat kita lihat, pada Tahun 2012 tingkat pengembalian kredit cenderung menurun. Pada kategori investasi sebanyak Rp. 619.856 merupakan kredit lancar hal ini dapat di lihat dari pengembalian kredit investasi Rp 619.856. modal kerja sebanyak Rp 230.283 dan pengembalian kredit konsumtif Rp 376.537.,dimana pada (tahun 2013) Rp 559.998 pengembalian kredit investasi menurun sebanyak Rp598.58, pengembalian modal kerja Rp193.623 dan kredit komsumtif Rp. 207.537 ini di katagorikan dalam perhatian khusus,dan pada tahun 2014 terjadi juga penurunan investasi sebanyak Rp 148.186 kredit modal kerja yang diperoleh Rp.120.488 serta kredit komsumtif yang di peroleh Rp.214.247.ini di katagorikan Kredit Kurang Lancar atau bermasalah.pada tahun 2014 kredit investasi yang di peroleh Rp. 304.917 dan kreit pengembalian modal kerja Rp. 110.247 serta pengembalian kredit komsumtif juga menurun Rp. 237.176. pengembalin kredit dari tahun ke tahun cenderung menurun, hal ini disebabkan oleh rendahnya pendapatan nasabah, yang artinya jika pendapatanya rendah maka kemampuannya dalam membayarkan kredit juga rendah .pada tahun 2012ini terjadi lancar atau bermasalah pada (tahun 2012 sampai 2013) dan (2014) tergolong Macet penurunan di kredit yang signifikan. Dari Lancar,menjadi perhatiaan khusus,kurang lancar atau kredit bermasalah dan kredit Macet. Dalam hal ini kredit yang di salurkan bank nagari cabang siteba.nasabah mengalami masalah, hal ini di sebabkan oleh merosotnya perekonomiaan, yang mengakibatkan lingkungan pengusaha dalam membayar angsuran pokok pinjaman mengalami masalah sehingga kredit lancar menjadi kurang lancar, diragukan bahkan macet..Selain kredit yang merajalela dalam masyarakat khususnya di menengah, keatas banyak bank yang menyimpang dari aturan dalam pemberian kredit,karna persaingan kredit yang ketat dalam penarikan nasabah.selain itu banyak kelalaian yang dilakukan bank dalam mengnalisis pemberian kredit dan pemberian jumlah yang tidak sesuai dengan kemampuan nasabahnya sehingga terjadilah kredit macet.mengingat demikian pentingnya ke giatan perkreditan bagi perbankan dimana ke gagalan yang terjadi pada perkreditan dapat mengakibatkan bank tersebut tidak sehat .pencabutan izin usaha yang di lanjutkan dengan likuidasi atas 16 buah bank pada tanggal 1 november 1997, disebabkan oleh banyak nya kredit bermasalah (non performing loans) yang sangat sulit di selesaikan .hal ini di picu pula oleh pelanggaran atas ketentuan-ketentuan atau rambu-rambu perkreditan yang di tetapkan Bank Indonesia.

Penyebab utama dari semua kejadian-kejadian tersebut adalah karena banyaknya kredit macet yang di sebabkan oleh pelanggaran-pelanggaran terhadap ketentuan ketentuan tentang pedoman kebijakan perkreditan bank.

Sesuai dengan kejelasan UU No.7 Tahun 1992 tentang perbankan ditegaskan bahwa "kredit yang diberikan oleh bank mengandung resiko, sehingga dalam pelaksanaannya bank harus dapat memperhatikan asa-asas perkreditan yang sehat". Agar pemberian kredit dapat dilaksanakan secara konsisten dan asas perkreditan yang sehat sehingga setiap bank diwajibkan membuat suatu kebijakan perkreditan secara tertulis yang dapat digunakan sebagai pedoman.

Kredit macet memberikan dampak yang kurang baik bagi Negara,masyarakat dan perbankan Indonesia.Adanya rentang waktu pengembalian pinjaman menimbulkan resiko yang sangat besar yang ditanggung oleh bank terhadap ketidakpastian pengembalian pinjaman dari debitur.Dengan adanya SK Direksi Bank Indonesia No.27/162/KEP/DIR tanggal 31 maret diharapkan dalam pemberian kredit dapat disesuaikan dengan kebutuhan sehingga tidak terjadinya kredit macet serta dapat mnyelesaikan kredit macet yang telah terjadi. 
Berdasarkan uraian di atas maka penulis tertarik untuk menuangkannya dalam bentuk tugas akhir dengan judul Analisis Faktor-Faktor Penyebab Kredit Macet Pada Bank Nagari Cabang Siteba .

Sesuai dengan judul dan pembahasan latar belakang yang telah disajikan sebelumnya,sebagai badan usaha yang bergerak menghimpun dana masyarakat dan menyalurkan dana tersebut dalam bentuk kredit Bank Nagari Cabang Siteba. tentunya peranan mengelola dalam mengurangi resiko yang akan ter jadi,untuk lebih terarah nya tugas akhir ini,maka rumusan masalahnya bagaimana analisis faktor-faktor penyebab kredit macet pada bank nagari cabang siteba .

Berdasarkan masalah diatas, maka tujuan penelitian adalah untuk mengetahui analisis faktor-faktor penyebab kredit macet pada bank nagari cabang siteba .

\section{LANDASAN TEORI}

Kredit berasal dari kata Romawi"credere" artinya percaya,dalam bahasa Belanda"Vertrowen" dalam bahasa Inggiris "Believe" atau "Trust" atau "confidance" artinya sama yaitu percaya (Sutomo 2005: 92). Dapat di simpulkan makna dari kata percaya adalah keyakinan dari bank sebagai kreditur bahwa kredit yang di berikan akan sungguh-sungguh di terima kembali dalam jangka tertentu sesuai dengan kesepakatan.

Undang-undang Republik Indonesia No. 10 tahun 1998 pasal 1, tentang perbankan,mengemukakan pengertian kredit yaitu penyediaan uang atau tagihan yang dapat di persamakan dengan itu, berdasarkan persetujuan atau kesepakatan pinjam meminjam antara bank dengan pihak lain yang mewajibkan pihak peminjam untuk melunasi uangnya setelah jangka waktu tertentu dengan pemberian bunga. Susilo (2002) mengemukakan jenis-jenis kredit sebagai berikut: jenis kredit di lihat dari

1. Segi kegunaannya:

a. Kredit Modal Kerja (KMK) merupakan kredit yang digunakan untuk keperluan meningkatkan produksi dalam operasional nasabah. Contoh: kredit modal kerja di berikan untuk membeli bahan baku, membayar gaji pegawai atau biaya-biaya lainnya yang berkaitan dengan proses produksi perusahaan.

b. Kredit Investasi (KI) merupakan kredit jangka panjang, biasanya di gunakan untuk keperluan perluasan usaha atau membangun proyek/pabrik baru serta untuk keperluan rehabilitasi. Contoh : kredit investasi misalnya membangun dan membeli mesin-mesin dan lainnya.

2. Jenis kredit dilihat dari segi tujuan penggunaan :

a. Kredit Konsumsi merupakan kredit ini di gunakan oleh peminjam untuk keperluan konsumsi, artinya uang kredit akan habis di pergunakan atau semua akan di pakai untuk memenuhi kebutuhannya.

b. Kredit Produktif merupakan kredit ini ditunjukkan untuk keperluan produksi dalam arti luas. kredit produktif di gunkan untuk peningkatan usaha, baik usahausaha produksi perdagangan maupun investasi.

c. Kredit perdagangan merupakan kredit ini di gunakan untuk keperluan perdagangan, pada umumnya yang berarti peningkatan utility of place dari suatu barang.

3. Macam menurut cara penarikan dana :

a. Cash Loan adalah kredit yang memungkinkan nasabah menarik dana tunai secara langsung tanpa adanya persyaratan khusus atau tertentu. Yang termasuk dalam kredit ini adalah kredit investasi dan kredit modal kerja. Nasabah dapat 
menarik dana tunai secara langsung untuk membiayai berbagai macam kegiatan usaha nasabah seperti modal kerja dan kebutuhan dana investasi.

b. Non Cash Loan adalah kredit yang tidak memungkinkan nasabah menarik dana tunai secara langsung tanpa adanya persyaratan khusus tertentu. Yang termasuk dalam kredit jenis ini adalah bank garansi dan letter of credit .

Jenis-jenis kredit dalam bisnis perbankan menurut Kuncoro dan Suhardjono (2002) dapat dikelompokkan sebagai berikut :

1. Pengelompokan kredit berdasarkan ciri dan tujuan penggunaanya, terdiri dari :

a. Kredit Konsumtif dimaksudkan untuk membiayai kebutuhan-kebutuhan yang bersifat konsumtif.

b. Kredit Modal Kerja yaitu kredit yang dipergunakan untuk menjalankan kegiatan usaha.

c. Kredit investasi yaitu kredit yang dipergunakan untuk melakukan investasi usaha atau keperluan usaha.

2. Pengelompokan kredit berdasarkan cara pelunasannya, antara lain kredit dengan angsuran tetap, kredit dengan plafond menurun setiap pride tertentu dan kredit dengan plafond tetap.

3. Pengelompokan kredit berdasarkan jangka waktu, antara lain kredit jangka pendek, kredit jangka menengah dan kredit jangka panjang.

4. Pengelompokan kredit berdasarkan besarnya fasilitas kredit, antara lain kredit kecil (misalnya kredit usaha kecil), kredit menengah dan kredit besar.

5. Pengelompokan kredit berdasarkan bentuk kredit, antara lain kredit berbentuk persekot dan kredit berbentuk rekening koran.

Penyaluran kredit menurut Kuncoro dan Suhardjono (2002) dapat diarahkan ke beberapa sektor ekonomi, antara lain :

1. Sektor pertanian misalnya perkebunan, kehutanan, pengadaan pangan dan sebagainya.

2. Sektor pertambangan misalnya tambang emas, batubara, minyak, gas alam dan sebagainya.

3. Sektor Perdagangan misalnya perdagangan hasil pertanian, hasil industry dan sebagainya.

4. Sektor perindustrian misalnya industri semen, industri mobil, industri makanan dan sebagainya.

5. Sektor jasa-jasa misalnya jasa konsultan, perbankan, rumah sakit dan sebagainya.

6. Sektor properti misalnya perumahan, perhotelan, perkantoran dan sebagainya.

Kredit memiliki tujuan, fungsi dan manfaat. Tujuan dari kredit antara lain :

1. Mendapakan Keuntungan, ni merupakan bentuk bunga yang di terima oleh bank sebagai balas jasa dan biaya administrasi kredit yang di bebankan kepada nasabah.

2. Membantu usaha nasabah, yaitu dana investasi maupun dana untuk modal kerja, dengan ini maka pihak debitur dapat mengembangkan dan memperluas usahanya.

3. Membantu Pemerintah yaitu semakin banyak kredit yang di salurkan oleh pihak perbankan,maka semakin baik, mengingat semakin banyak kredit berarti adanya peningkatan pembangunan di berbagai sektor.

Menurut Suyanto (2003: 15) tujuan pemberian kredit adalah sebagai berikut:

1. Keamanan (safety) merupakan prestasi

2. Keuntungan (profitability) adalah merupakan tujuan dari pemberian kredit yang dapat di terima dalam bentuk bunga.

Manfaat dari kredit dapat di lihat sebagai berikut : 
1. Bagi debitur yaitu dapat meningkatkan usahanya dengan pengadaan berbagai faktor produksi. kredit bank relatif mudah di peroleh apabila usaha debitur layak di biaya dengan jumlah yang banyak memudahkan calon debitur memilih bank yang cocok dengan usahanya.

2. Bagi bank yaitu memperoleh pendapatan dari bunga yang diterima dari dari debitur, dengan adanya bunga kredit di harapkan rentabilitas bank akan membaik dan dapat memperolehkan laba yang meningkat.Dengan pemberian kredit akan membantu dalam memasarkan produk atau jasa perbankan lainnya. Dengan pemberian kredit bank dapat meningkatkan pangsa pasar dalam industry perbankan serta pemberian kredit tersebut dapat mempertahankan dan mengembangkan usaha bank.

3. Bagi pemerintah yaitu alat untuk memacu pertumbuhan ekonomi secara umum dan menciptakan dan memperluas pasar.

4. Bagi masyarakat yaitu mendorong pertumbuhan dan memperluas ekonomi, mengurangi tingkat pengangguran, meningkatkan pendapatan masyarakat, memberikan rasa aman bagi masyarakat yang menyimpan uangnya di bank.Pada dasarnya kredit yaitu uang bank yang di pinjamkan ke pada nasabah dan akan di kembalikan pada waktu tertentu atau di masa mendatang, dengan disertai dengan kontrak prestasi berupa bunga. Tetapi berdasarkan keperluan usaha serta berbagai unsur ekonomi yang mempengaruhi bidang usaha nasabah.

Kredit yang di berikan oleh lembaga kredit di dasarkan atas kepercayaan sehingga dengan demikian pemberian kredit merupakan pemberiaan kepercayaan. Ini berarti bahwa suatu lembaga kredit baru akan memberikan kredit kalau ia betul-betul yakin bahwa si penerima kredit akan mengembalikan pinjaman yang diterimanya sesuai dengan jangka waktu dan syarat-syarat yang telah disetujui oleh kedua belah pihak. Tanpa keyakinan tersebut, suatu lembaga kredit tidak akan meneruskan simpanan masyarakat yang di terimanya. Suyatno (2000) mengemukakan unsur-unsur yang terdapat dalam kredit yaitu:

1. Kepercayaan yaitu kepercayaan atau keyakinan dari si penerima kredit bahwa prestasi yang di berikannya, baik dalam bentuk uang, barang atau jasa akan benarbenar di terimanya kembali dalam jangka waktu tertentu di masa yang akan datang.

2. Waktu yaitu waktu yaitu suatu masa yang memisahkan antara pemberian prestasi dengan kontra prestasi yang akan di terima pada masa yang akan datang karena uang yang ada sekarang lebih tinggi nilainya dari uang yang akan di terima di masa yang akan datang.

3. Tingkat Resiko yaitu suatu tingkat resiko yang akan di hadapi sebagai akibat dari adanya jangka waktu yang memisahkan antara pemberi prestasi dengan kontra prestasi yang akan di terima dikemudian hari. Semakin lama kredit yang akan di berikan maka semakin tinggi pula tingkat resikonya.

4. Prestasi yaitu objek kredit itu tidak saja di berikan dengan bentuk uang tetapi dapat pula berbentuk barang atau jasa. Namun karena kehidupan ekonomi modern sekarang ini didasarkan pada uang, maka transaksi-transaksi kredit yang menyangkut uanglah yang sering kita jumpai dalam praktek kredit perkreditan.

5. Penyerahan yaitu adanya suatu penyerahan uang atau tagihan yang bisa juga berupa barang dan jasa yang menimbulkan tagihan pada pihak lain dengan harapan pemberi pinjaman atau bank akan memperoleh suatu tambahan nilai dari pokok pinjaman tersebut berupa bunga sebagai pendapatan dari bank tersebut.

6. Persetujuan yaitu dalam pemberian kredit terkandung persetujuan untuk melunasi hutang pokok (principal)dan hutang bunga(inters) dalam jangka waktu tertentu. 
Pemberian kredit merupakan kegiatan utama bank yang mengandung resiko yang dapat berpengaruh pada kesehatan dan kelangsungan usaha bank, sehingga dalam pelaksanaannya bank harus berpegang pada azas-azas perkreditan yang sehat, guna melindungi dan memelihara kepentingan dan kepercayaan masyarakat. Sehingga diperlukan suatu kebijakan perkreditan yang tertulis. Berkenaan dengan hal tersebut, Bank Indonesia telah menetapkan ketentuan mengenai kewajiban bank umum untuk memeliki dan melaksanakan kebijakan perkreditan bank berdasarkan pedoman penyusunan kebijakan perkreditan bank dalam SK Dir No.27/162/KEP/DIR tanggal 31 maret 1995. Berdasarkan SK Dir BI tersebut, Bank Umum wajib memiliki kebijakan perkreditan bank secara tertulis yang di setujui oleh dewan komisaris bank dengan sekurang-kurangnya memuat dan mengatur hal-hal pokok sebagai berikut:

1. Prinsip kehati-hatian dalam perkreditan.

2. Organisasi manajemen perkreditan.

3. Kebijakan persetujuan kredit.

4. Dokumentasi dan administrasi kredit.

5. Pengawasan kredit.

6. Penyelesaian

Analisis kredit adalah suatu proses analisis kredit dengan menggunakan pendekatan-pendekatan dan rasio-rasio keuangan untuk menentukan kebuuhan kredit yang wajar.Pengertian analisis kredit menurut suyatno(2003:70)adalah pekerjaan yang meliputi:

1. Mempersiapkan pekerjaan-pekerjaan penguraian dalam segala aspek,baik keuangan maupun non keuangan untuk mengetahui kemungkinan dapat atau tidak di pertimbangkan suatu permohonan kredit.

2. Menyusun laporan analisis yang diperlukan yang berisi penguraian dan kesimpulan serta penyajiaan altrnatif-alternatif sebagai bahan pertimbangan untuk pengambilan keputusan pimpinan dari permohonan kredit nasabah.

Menurut Rivai(2006:288) tujuan analisis kredit adalah untuk memperoleh

keyakinan apakah nasabah mempunyayi kemauan memenuhi kewajibannya secara tertib kepada bank,baik pembayaran pokok pinjaman maupun bunganya sesuaia kesepakatan dengan bank.

Hal yang perlu di perhatikan dalam menganalisis kredit, yaitu nasabah harus memenuhi prinsip $6 \mathrm{C}$ yaitu ebagai berikut:

1. character adalah keadaan watak/sifat nasabah baik dalam kehidupan pribadi maupun dalam lingkungan usaha.keunaan karakter ini adalah untuk mengetahui sejauh mana itikad/kemampuan nasabah umtuk memenuhi kewajibannya sesuai ddengan perjanjian yang telah di tetapkan.sebagai alat untuk memperoleh gambaran tentang karakter dari calon nasabah tersebut,dapat di lihat melalui upaya antara lain:

a. Melihat riwayat hidup calon nasabah.

b. Meneliti reputasi calon nasabah tersebut dilingkungan usahanya.

c. Meminta informasi dari bank lain.

d. Mencari informasi kepada assosiasi usaha dimana calon nasabah berada.

e. Mencarai informasi apakah calon nasabah suka berjudi atau berfoya-foya

2. capital adalah jumlah dana/modal sendiri yang dimiliki oleh calon nasabah.Semakin besar modal sendiri dalam perusahaaan,semakin tingggi kesungguhan calon nasabah dalam menjalankan usahanya dan bank akan merasa lebih yakin dalam memberikan kredit. 
3. Capacity adalah kemampuan yang dmiliki calon nasabah dalam menjalankan usahanya guna untuk memperoleh laba yang diharapkannya.dari penilaiaan ini adalah untuk mengetahui sejauh mana calon nasabah mampu untuk mengembalikan atau melunasi hutang-hutangnya secara tepat waktu dari usaha yang di perolehnya.pengukuran capacity tersebut dapat dilakukan melalui berbagai pendekatan berikut ini:

a. Pendekatan historis,yaitu menilai past formance apakah menunjukan perkembangan dari waktu kewaktu.

b. Menilai pendekatan financial, yaitu menilai latar belakang pendidikan para pengurus.

c. Pendekatan yuridis, yaitu secara yudiris apakah calon nasabah mempunyanyi kapasitas untuk mewakili badan usaha yang diwakilinya untuk mengadakan perjanjian kredit dari bank.

d. Pendekatan manajerial, yaitu menilai sejauh mana kemampuan dan keterampilan nasabah melaksanakan fungsi-fungsi manajemen dalam memimpin perusahaan.

e. Pendekatan teknis, yaitu untuk menilai sejauh mana kemampuan calon nasabah mengelola faktor-faktor produksi ,seperti tenaga kerja,sumber bahan baku,peralatan-oeralatan mesin admnistrasi,dan keuangan.

4. Collateral adalah barang-barang yang di serahkan nasabah sebagai agunan terhadap kredit yang di terimanya.Penilaian terhadap collateral ini dapat di tinjau dari dua segi sebagai berikut:

a. Segi ekonomi, yaitu nilai ekonomi dari barang-barang yang akan di agunkan.

b. Segi yudiris, yaitu apakah jaminan tersebut memenuhi syarat-syarat yuridis untuk dipakai sebagai jaminan.

5. Constraint of economy adalah situasi dan kondisi polotik, social, ekonomi, budaya yang mempengaruhi keadaan perekonomiaan pada suatu saat yang kemungkinanya mempengaruhi kelancaran perusahaan calon debitur.

6. Constraint adalah batasan dan hambatan yang tidak memungkinkan suatu bisnis untuk melaksanakan pada tempat tertentu.

Menurut Kasmir ( 2003 :104 ), Penilaian kredit dapat dilakukan menggunakan asas 5C, 7P dan 3R.Yang termasuk kedalam 5C antara lain:

1. Character (watak) yaitu suatu keyakinan bahwa,sifat atau watak dari orang-orang yang akan di beri kredit yang benar-benar dapat di percaya,hal ini tercermin dari latr belakang nasabah ,baik yang bersifat latar belakang pekerjaan maupun yang bersifat pribadi,seperti cara hidup atau gaya hidup yang di anutnya dan keadaan keluarganya.

2. Capacity (Kemampuan) yaitu untuk melihat kemampuan nasabah dalam bidang bisnis yang di hubungkan dengan pendidikannya,kemampuan bisnis juga dapat di ukur dengan kemampuaannya dalam memahami tentang ketentuan-ketentuan pemerintah. Begitu pula dengan kemamuannya dalam menjalankan usahanya selama ini.pada akhirnya akan terlihat kemampuannya dalam mengembalikan kredit yang disalurkannya.

3. Capital (modal) yaitu untuk melihat penggunaan modal apakah efekti,dapat dilihat dari laporan keuangan(neraca dan laporan laba/rugi) dengan melakukan pengukuran seperti dari segi likuidilitas, solvabilitas,rentabilitas dan ukuran lainnya.kapital juga harus di lihat dari sumber mana saja modal yang ada sekarang ini.

4. Collateral (agunan) yaitu merupakan jaminan yang di berikan calon nasabah,baik yang berupa fisik maupun non fisik.jaminan hendaknya melebihi jumlah fisik kredit 
yang di berikan.Jaminan ini juga harus I teliti keabsahanya sehingga jika terjadi sesuatu masalah,maka jaminan yang di titipkan akan dapat di pergunakan.

5. Condition (kondisi) yaitu dalam penilaian kredit hendaknya juga di nilai kondisi ekonomidan politik sekarang dan di masa yang akan datang sesuai sektor masingmasing.serta prospek usaha yang dibiayai hendaknya benar-benar memiliki prospek yang baik,sehingga kemungkinan kredit tersebut bermasalah atau macet relative kecil. Penilaian berdasarkan asas 7P dapat dilihat sebagai berikut:

1. Personality yaitu menilai nasabah dari segi kepribadianya atau tingkah lakunya sehari-hari.personality juga mencangkup sikap,emosi,tingkah laku dan tindakan nasabah dalam menghadapi suatu masalah.

2. Party yaitu mengklasifikasikan nasabah kedalam klasifikasi tertentu atau golongangolongan tertentu berdasarkan modal,loyalitas serta krakternya.sehingga nasabah dapat di golongkan ke golongan tertentu dan akan mendapatkan fasilitas yang berbeda dari bank.

3. purpose yaitu untuk mengetahui tujuan nasabah dalam mengambil kredit,termasuk jenis kredit yang di inginkan nasabah.tujuan kredit dapat bermacam-macam .sebagai contoh apakah untuk modal kerja,investasi,komsumtif dan lainnya.

4. prospek yaitu untuk menilai usaha nasabah di masa yang akan datang menguntungkan atau tidak,atau dengan kata lain mempunyanyi prospek atau tiadak.

5. Payment yaitu merupakan ukuran bagaimana cara nasabah mengembalikan kredit yang telah di terima,atau dari mana saja sumber dana pengambialan kredit.semakin banyak sumber dana debitur maka semakin baik.sehingga jika salah satu usahnya merugi akan dapat di utupi dari sektor lainnya.

6. profitability yaitu untuk menganalisis bagaimana kemampuaan nasabah dalam mencari laba.Profitability diukur dari priode ke priode apakah akan tetap sama atau akan semakin meningkat,apalagi dengan tambahan kredit yang di perolehnya.

7. Protection yaitu tujuan adalah bagaimana menjaga agar usaha dan jaminan mendapat perlindungan.perlindungan dapat berupa jaminan barang atau orang jaminan asuransi.

Dan penilaian yang berdasarkan atas asas $3 \mathrm{R}$ terdiri dari:

1. Returns yaitu penilaian terhadap hasil yang akan di capai perusahaan calon debitur setelah memeroleh krredit.

2. Repayment yaitu menghitungkan kemampuan,jadwal dan jangka panjang wakatu pembayaran kredit oleh calon debitur, tetapi perusahaan tetap berjalan.

3. Risk Bearing Ability yaitu menghitungkan besarnya kemampuan perusahaan calon debitur untuk menghadapi resik.jika resiko perusahaan besar,maka kredit tidak aan di berikan, tetapi jika resiko perusahaan kecil maka kredit dapat di berikan.

Untuk melihat kualitas aktiva produktif bank dan seberapa jauh kredit macetyang terdapat pada bank tersebut dapat dinilai berdasarkan kolektabilitas kreditnya. Klektabilitas kredit adalah keadaan pembayaran pokok atau angsuran pokok dan bunga kredit oleh nasabah serta tingkat kemungkinan diterimanya kembali dana yang di tanamkan dalam surat-surat berharga. Dengan melihat kolektabilitas kredit kita dapat menilai kualitas kredit yang diberikan:

Kolektabilitas kredit dapat di bedakan atas lima jenis yaitu:

1. Lancar, yaitu tampa tunggakan.

2. Dalam perhatian khusus, yaitu kredit mempunyanyi tunggakan pokok atau bunga 1 s/d 90 hari

3. Kurang lancar, yaitu kredit yang mempunyanyi tunggakan pokok atau bunga 91s/d 180 hari 
4. Diragukan,yaitu kredit yang mempunyanyi tunggakan pokok atau bunga $181 \mathrm{~s} / \mathrm{d} 270$ hari

5. Macet, yaitu kredit yang mempunyanyi tunggakan pokok atau bunga leboh dari 270 hari.

Secara umum, penyebab munculnya kredit macet dapat di kelompokkan menjadi 3 (tiga) penyebab yaitu:

1. Faktor Intern.

a. Bank melakukan kebijakan pemberian kredit yang teralu ekspensif dan agresif untuk mengejar target pemberiaan dan pertumbuhan kredit yang tinggi dan relatif singkathingga prosedur pemberiaan kredit yang sehat terabaikan.

b. Bank tidak melakukan penyebaran resiko dalam kebijakan pemberiaan kredit dan lai-lainya.

2. Faktor debitur.

a. Itikad yang tidak baik dari debitur dan adanya kesengajaan melakukan perbuatan melawan hukum terhadap bank dengan bermacam modus operandi, antara lain dideteksi dari sikap perbuatan debitur sebagai berikut:

b. Kelemahan Manajemen, antara lain:

1) Struktur permodalan atau keuangan sangat lemah.

2) Prospek keuangan kurang baik.

3) Kurang pengalamandalam mengelola usaha sesuai dengan kondisi dan situasi yang berkembang dan lain-lainya.

\section{Faktor Ektern:}

a. Kondisi perekonomiaan/politik/kebijakan pemerintah yang diluar jangkauan untuk di perkirakan.

b. Adanya tekanan -tekanan dari berbagai kekuatan politis di luar bank.

c. terjadinya bencana alam dan sebagainya.

Tujuan penyelesaian kredit macet dan penanganan dan penyelesaian kredit macet bertujuan untuk:

1. Menjaga dan memperbaiki rasio uncollectibility dan Non Performing Loan (NPL) yang digolongkan sehat sesuai dengan business Plan Bank atau peraturan Bank Indonesia.

2. Meningkatkan kesehatan Bank

3. Memperoleh kembali dana Bank dan sekaligus meningkatkan pendapatan.

4. Menjaga kesenambungan usaha Bank.

\section{METODE PENELITIAN}

Dalam pengumpulan data dan bahan untuk melakukan penelitian ini, digunakan metode-metode pengumpulan data, sebagai berikut :

1. Studi Lapangan ( Field Research)

Peninjauan langsung ke objek penelitian di pilih untuk meneliti hasil data primer. Penelitian langsung ke lapangan ini akan dapat membantu penulis untuk melengkapi data yang diperlukan. Adapun cara riset lapangan ini adalah dengan mewawancarai pihak-pihak yang berkepentingan dalam hal ini adalah perusahaan atau instansi yang terkait.

2. Studi Kepustakaan ( Library Research )

Penelitian yang dilakukan ke perpustakaan beberapa buku-buku ilmiah dan tulisantulisan yang berhubungan dengan pembahasan yang dilakukan. 
Dalam mengangalisa data, penulis menggunakan analisis data kualitatif sebagai metode penelitian yang menjelaskan secara deskriptif mengenai pelaksanaan pemberian kredit pada Bank Nagari.

Metode analisis ditinjau dari dua segi yang berbeda yaitu antara teori dan praktek yang perlu diterapkan, sehingga dapat diketahui sejauh mana pelaksanaannya, apakah perbedaan yang timbul menyangkut prinsip dasar konsep itu sendiri, pertanyaan itu akan terjawab, selanjutnya dari hasil analisa itu digunakan sebagai dasar pengambilan kesimpulan dan saran.

\section{HASIL DAN PEMBAHASAN}

Setiap penyaluran kredit oleh bank tentu mengandung resiko, karena adanya keterbatasan kemampuan manusia dalam memprediksi masa yang akan datang. Apalagi dalam situasi dan kondisi lingkungan yang cepat berubah dan tidak ketidakpastian seperti sekarang ini. Beberapa hal yang penting yang harus di lakukan oleh bank dalam menekan atau mengurangi seminimal mungkin resiko pemberian kreditnya. Dalam pemberian pembiayaan terdapat masalah-masalah dalam pemberiaan pembiayaan tersebut, seperti adanya kredit macet atau di sebut juga dengan Non Performing Financing (pembiayaan bermasalah), yang dalam hal ini banyak faktor-faktor yang menyebabkan kredit macet (pembiayaan). Dalam hal ini, saya melihat keadaan kredit macet menjadi masalah bagi bank ,kerena apabila kredit macet maka bank akan mengalami kerugian.

Pemberiaan pembiayaan, menurut UU no. 10 tahun 1998 pasal 8 dilakukan berdasarkan analisa dengan menetapkan prinsip kehati-hatian utangnya atau mengembalikan pembiayaan sesuai dengan perjanjian sehingga resiko kegagalan atau kemacetan dalam pelunasan dapat di hindari. Walaupun demikian pembiayaan yang di berikan kepada nasabah tidak akan pernah lepas dari resiko terjadinya pembiayaan bermasalah yang akhirnya dapat mempengaruhi kinerja bank ataupun lembaga keuangan lainnya.

Banyak faktor-faktor yang menyebabkan terjadinya pembiayaan bermasalah atau macet. Pada Bank Bank Nagari Cabang Siteba, faktor-faktor yang menyebabkan pembiayaan bermasalah ini di antaranya adalah karena karakter nasabah, rasio modal (capital) terhadap hutang (leverage) serta jumlah jaminan.

Secara teori Firdaus dan aryanti dalam bukunya yang berjudul manajemen perkreditan bank umum tahun 2008 menjelaskan bahwa karakter atau watak merupakan salah satu pertimbangan yang terpenting dalam memutuskan pemberiaan kredit. Bank sebagai pemberi kredit harus yakin bahwa calon peminjam kredit harus bertingkah laku baik, dalam arti harus berpegang teguh terhadap janjinya. Selalu berusaha dan bersedia melunasi utang-utangnya sesuai dengan waktu yang telah ditetukan. Sehingga apabila calon peminjam tersebut merupakan pribadi yang berkarakter kurang baik atau jelek, maka kemungkinan untuk pengembalian pembiayaan kemungkinaan akan terjadi. Kemudiaan aspek kekayaan (equity) yang di miliki oleh calon peminjam atau perusahaan dan rasionya terhadap hutang (leverage). ini di padang sebagai prediktor probabilitas kebangkrutan yang baik, leverage yang tinggi di pandang mempunyai protabilitas yang tinggi pula. apabila tingkat hutang yang dialami akan tinggi pula, sehingga untuk tingkat pengembalian pembiayaan akan tinggi begitupun sebaliknya. Selain itu, pemberian jaminan juga memiliki kontribusi juga terhadap terjadinya pembiayaan bermasalah. 
Firdaus dan Aryanti memberikan penjelasan collateral sebagai jaminan atau agunan,yaitu harta benda milik debitur atau pihak ke-3 yang di ikat sebagai agunan andai kata terjadi ketidak mampuan debitur menyelesaikan utangnya sesuai dengan perjajian kredit.dengan kata lain,pemberian jaminan yang dilakukan oleh bank kepada debituratau kepada calon peminjam yang dimaksudkan untuk berjaga-jaga kemungkinan terjadi pembiayaan bermasalah kemudiaan sebagai menjalankan fungsi pemberiaan jaminan yaitu sebagai fungsi kehati-hatian atau jaga-jaga serta sebagai jumlah penentu kredit yang akan diberikan dengan cara menentukan jumlah jaminan.

Dalam penilaian kredit ada prinsip-prinsip yang harus di perhatikan yaitu prinsip $5 c+1 c$ yang meliputi, character adalah watak sangat menentukan kemauan untuk membayar kredit yang telah di terimanya, capacity adalah kemampuan debitur dalam mengelola usahanya, capital adalah informasi mengenai besar kecilnya modal (capital) perusahaan calon debitur sangat penting bank, collateral (jamnan kredit) merupakan setiap aktiva atau barang-barang yang di serahkan debitur sebagai jaminan atas kredit yang di peroleh dari bank, conditions adalah keadaaan perekonomian secara umum dimana perusahaan tersebut beroperasi, constraint adalah mempertimbangkan hambatan yang akan muncul di lapangan. Dalam pedoman Pelaksanaan kredit ini,yang di maksudkan dengan:

1. Bank, adalah Bank Nagari Cabang Siteba

2. Direksi,adalah Direksi Bank Nagari Cabang Siteba

3. Dewan komisaris, adalah dewan komisaris Bank Nagari Cabang Siteba

4. Komite kredit adalah komite operasional yang membantu pejabat pemutus kredit dalam evaluasi atau memutuskan permohonan kredit untuk jumlah dan jenis kredit yang di tetapkan oleh Direksi.

5. Komite Restrukrisasi kredi,adalah komite operional yang membantu pejabat pemutus kredit dalam mengevaluasi atau memutuskan permohonan restrukturisasi kredit untuk jumlah dan jenis kredit yang ditetapkan direksi.

6. Pejabat Kredit,adalah seluruh persenil bank terkait dengan proses perkreditan bank termasuk Dewan komisaris dan Direksi.

7. Pejabat pemutus kredit,adalah pejabat yang ditetapkan memiliki wewenang melalui surat keputusan direksi untuk memutuskan kredit menurut jumlah tertentu baik melalui komite kredit.

8. Satuan kerja perkreditan ,adalah unit-unit kerja dalam struktur organisasi bank yang terlibat dalam pengelolaan kredit.

9. satuan perkreditan pusat ,adalah unit kerja di kantor pusat yang trlibat dalam pengelolaan kredit.

10. Satuan kerja perkreditan cabang,adalah unit kerja di kantor cabang yang terlibat dalam pengelolaan kredit.

11. Bank yang menghadapi kredit macet,adalah bank yang jumlah kredit dengan kualitas tergolong di ragukan (D)dan Macet(M)mencapai 7,50\%(tujuh koma lima puluh persen) dari total kredit yang di berikan.dan kreteria tersebut sewaktu-waktu dapat di ubah oleh Bank Indonesia,dan Kebijakan Perkreditan Bank(KPB) ini dinyatakan menyesuaikan terhadap perubahan tersebut.

12. Dokument kredit,adalah seluruh dokumen yang di perlukan dalam rangka penyaluran kredit yang merupakan bukti perjajian/ikatan hukum antara bank da debitur dan dokumen piñatausahaan kredit sejak pemohonan sampai dengan kredit lunas 
13. Jaminan,adalah keyakinan bank atass kessanggupan debitur untuk melakukan kewajibannya sesuai debgan perjanjian dan telah melakukan penilaian yang saksama terhadai watak,kemampuan modal dan prospek debitur.

14. Kebijakan perkreditan bank,adalah pedoman umum perkreditan yang memuat kebijakan umum kebijakan pokok,prinsp kehati-hatan ,organisasi manajement,kebijakan persetujuan kredit ,dokumentasi dan administrasi pengawasan dan pembinaaan serta penyelesaian kredit macet.

15. Kredit adalah penyediaan uang atau tagihan yang dapat di persamakan dengan itu,berdasarkan persetujuan atau kesepakatan pinjam meminjam antara bank dan pihak lain yang mewajibkan pihak peminjam untuk melunasi hutangnya setelah jangka waktu tertentu dengan pemberian bunga.

16. kredit macet adalah kredit yang pengambilan hutang pokok maupun bunga dan pembayaran kewajiban lainnya terjadi tunggakan atau tidak sesuai dengan perjanjian kredit yang telah di sepakati.

17. Restrukturisasi kredit adalah upaya bank untuk melakukan tindakan penyelamatan terhadap kredit yang telah di perkirakan akan mengalami kesulitan pembayaran ansuran pokok atau bunga kredit.sesuai dengan cara-cara yang di tetapkan oleh Bank Indonesia yang berlaku.

Identifikasi dan Strategi Penyelesaian Kredit Macet Pada Bank Nagari Cabang Siteba.

1. Langkah penyelamatan kredit macet.

Yang dimaksud dengan penyelamatan kredit adalah adanya upaya -upaya bank untuk melancarkan kembali kredit yang tergolong tidak lancar atau di ragukan bahkan tergolong macet untuk kembali menjadi kredit lancar, sehingga kembali mempunyai kemampuan untuk membayar kepada bank, baik bunga maupun pokoknya.Penyeleaian kredit macet secara damai merupakan salah satu upaya dalam penyelesaian kredit, ini dilakukan berdasarkan kesepakatan antara bank dengan debitur yang masih mempunyai itikad baik maupun koperatif dalam menyelesikan pinjamannya, tetapi tidak mempunyai kemampuan yang cukup untuk menyelesaikannya sedangkan dari segi bisnis kondisi usahanya masih layak dan mungkin untuk dipertahankan serta mempunyai prospek yang baik.

2. Identifikasi penyelesaian

Untuk mencapai sasaran dan tujuan dalam penyelesaian kredit macet,bank melakukan identifikasi dan analisa permasalahan untuk penyelesaian kredit macet yang merupakan dasar dalam penetapan strategi guna memperkecil kerugian, dengan focus penilaian terhadap kemampuan membayar kredit,kecukupan agunan dan kredibilitas manajemen debitur dengan proses analisa sebagai berikut:

a. Melakukan identifikasi terhadap permasalahan yang di hadapi oleh debitur dengan memfokuskan kepada penelitian gejala dan penyebab terjadinya kredit macet serta menentukan permasalahan yang tengah dihadapi debitur.

b. Melakukan analisis secara menyeluruh,cepat dan tepat dari permasalahan untuk dapat menentukan sejauh mana kerugian yng terjadi.

3. Strategi Penyelesaian

Strategi yang tepat sangat menentukan keberhasilan yang maksimal dalam penyelesaian kredit macet, sehingga kerugian terhadap kredit macet akan dapat ditekan seminimal mungkin. Untuk menetapkan strategi penyelesaian kredit macet di lakukan langkah-langkah sebagai berikut.: 
a. Menginventarisir permasalah yang dihadapi oleh debitur,terhadap fokus penilaian meliputi kemampuan membayar, Agunan dan kredibilitas manajemen debitur.

b. Menentukan sasran strategi yang optimal dengan memperbaiki fokus yang dinilai dan memperkuat agar risiko kredit tidak terlalu besar tinggi, karena kelemahan dari salah satu fokus yang di nilai dapat melemahkan fokus lain nya.

c. Mempertimbangkan berbagai macam strategi untuk memperbaiki fokus yang lemah dan di dukung dengan suatu rencana tindakan(Action plan) yang terici dan jelas, dengan cara sebagai berikut:

Kelemahan kemampuan membayar debitur, dapat memperbaiki dengan cara:

Efesiansi atau penghematan biaya operasional usaha.

1. Menjual aktiva yang tidak produktif.

2. Menjadwalkan kembali ngsuran kredit sesuai kemampuan cash flow dan lain-lain.

3. Kelemahan dari agunan kredit, dapat dilakukan dengan meminta tambahan agunan kepada debitur.

4. Kelemahan dari kredibilitas manajeman debitur, dapat dilakukan dengan pembinaan penggantian manajemen.

5. Melakukan pemilihan strategi dari 2 (dua) pilihan yaitu:"Memutuskan Hubungan Kredit",dan atau "Meneruskan Hubungan Kredit". Pemilihan dari salah satu strategi tersebut harus di dukung oleh rencana dan tindakan (Action plan) yang kongkrit.

6. Membuat rencana tindakan (Action plan) yang kongkrit untuk pedoman pelaksanaan strategi antara lain:

a. Menentukan tugas-tugas yang akan di laksanakan secra jelas dan rinci.

b. Menentukan batas atau target waktu pelaksanakan dari tugas-tugas atau langkah tindakan.

c. Menetapkan atau mendelegasikan tanggung jawab

d. dan kewenangan untuk melaksanakan tugas-tugas atau langkah tindakan.

e. Menentukan hasil yang di harapkan.

Untuk penyelesaian dan menyelamatkan kredit yang dikatagorikan macet,dapat di tempuh dengan usaha-usaha sebagai berkut: (Siamat,1993 hal222-223)

1. Rescheduling (Penjadwalan uang) yaitu perubahan syarat kredit hanya menyangkut jadwal pembayaran atau jangkau termasuk masa tenggang(grace priod)dan perubahan besarnya angsuran kredit.

2. Reconditoning (persyaratan uang) yaitu perubahan sebagian atau seluruh syaratsyarat kredit yang tidak terbatas pada perubahan jadwal pembayaran,janka waktu,tingkat suku bunga,penundaan pembayaran sebagian atau seluruhbunga dan persyaratan lainnya.

3. Restructuring (penataan uang) yaitu seluruh atau sebagian tunggakan bunga menjadi pokok kredit baru atau sebagiaan dari kredit menjadi penyertaan bank.

4. Liquidation (liquidasi) yaitu penjualan barang-barang yang dijadfikan jaminan dalam rangka pelunasan hutang.

Langkah -langkah kebijakan yang harus dilakukan oleh bank dalam menyelesaikan kredit macet sebagai berikut :

1. Kebijakan Umum

Penagihan kredit secara langsung oleh bank merupakan upaya pertama yang dilakukan sebagai antiifasi atau tindakan prepentif atas segala hal munculnya kredit bermasalah.

a. Langkah pelaksanaan Penagihan 
b. Dalam melakukan penagihan dapat dipedomani beberapa langkah berikut ini yang urutannya di sesuaikan dengan peluang keberhasilannya,yaitu:Investasi data tunggakan dan permasalahan yang menyebabkan kredit menjadi macet.

1) Menetapkan prioritas penagihan, yaitu:

a) Kualitas kredit dalam perhatiaan khusus.

b) Kualitas kredit kurang lancer.

c) Kualitas kreditdiragukan.

d) Kualitas kredit macet.

e) Kredit yang dicatat secara Ekstrakomtabel.

2) Melakukan Pendekatan secara persuasif dengan debitur, meliputi:

a) Mengirimkan surat peringatan dan memanggil debitur ke kantor.

b) Melakukan kunjungan secara rutin.

c) Membicarakan penyebab terjadinya kredit macet.

d) Membicarakan langkah-langkah penyelesaian atau penyelamatan kredit.

e) Membuat action plan yang di tuangkan dalam daily client visiting Report.

3) Menegosiasikan dengan debitur tentang langkah-langkah penyelesaian, seperti:

a) Penyelamatan kredit.

b) Penyelesaian kredit.

c) Pelunasan kredit.

d) Angsuran dalam janka waktu tertentu.

e) Angsuran dengan pemberian keringanan bunga dan denda kredit.

f) Penyelesaian melalui penjamin.

g) Menjual angsuran kredit, dan lain-lainya.

h) Membuat dan menyampaikan surat teguran kepada debitur:

i) Surat teguran kredit adalah pemberitahuaan kepada debitur bahwa telah terjadi tunggakan pokok atau bunga kredit, dengan permintaan untuk segera menyelesaikan tunggakan keweajiban tersebut.

j) surat tunggakan ditembuskan kepada pemilik angunan dan penjamin kredit.

k) Surat teguran diberikan pada kesempatan pertama, sejak penurunan kualitas kredit dari lancer menjadi dalam pehatiaan khusus.

1) Surat teguran dapat di berikan secara berulang-ulang, selama kualitas kredit tergolong dalam perhatiaan khusus.

m) Membuat serat teguran diatur dengan Surat Direksi terdiri dari.

n) Membuat dan menyampaikan Surat peringatan.

o) Surat peringatan adalah suatu permintaan/perintah dari bank kepada kepada debitur intuk segera menyelesaikan kewajiban tunggakan,surat peringatan ini disamapaikan Bank kepada debitur apabila upaya pendekatan secara persuasife yang di lakukan terhadap debitur tidak membuahkan hasil yang diharapkan.Pengaturan pemberian surat peringatan . Surat peringatan I (SP I) di berikan kepada kesempatan pertama sejak penurunan kualitas kredit dari dalam perhatian khusus menjadi kurang lancar.Surat peringatan II(SP II) diberikan pada kesempatan pertama sejak penurunan kualitas kredit dari yang di ragukan menjadi macet.Format surat peringatan diatur dengan surat Direksi tersendiri: 
4) Surat peringatan di tembuskan kepada:

a) Pemilik agunan dan penjamin kredit.

b) Pihak yang di rasa perlu.

5) Debitur menjual sendiri angunan kredit.

Debitur mencari sendiri pembeli agunan,dan dalam proses penjualannya harus mendapatpatkan persetujuaan dar bank.

6) Menjual berdasarkan Surat kuasa dari debitur atau pemilik anggunan debitur , atau pemilik angunan member surat kuasa kepada bank atau pihak lain untuk menjual agunan kredit gunanya untuk menyelesaikan tunggakan kredit bank. Format surat kuasa diatur dangan surat Direksi tersebut.

7) Bank menjual angunan berdasarkan kesepakatan kedua belh pihak dengan tata cara sebagai berikut:

a) Adanya kesepakatan kedua belah pihak.

b) Harga jual sesuai dengan harga umum yang di pasarkan.

8) Melakukan penagihan kepada penjamin kredit dengan cara sebagai berikut:

a) Memanggil penjamin kredit untuk datang ke bank, atau mengunjungi penjamin kredit.

b) Membicarakan langkah-langkah penyelesaian kredit yang di jamin.

c) Mempertemukan debitur dengan penjamin kredit.

9) Pengajukan klaim kepada Lembaga Penjamin Kredit yang di tutup dengan pertanggungan kredit. Tata cara dan prosedur penutupan pertanggungan dan pengajuan klaim melaksanakan penyelesaian kredit mempedomani perjanjian kerja sama pertanggunan kredit antara bank degan lembaga penjamin yang dimaksud.

Pengawasan dan penanganan kredit selama ini, merupakan salah satu uasaha dari Bank Nagari Cabang siteba, untuk mencega timbulnya kredit macet. Kewenangan untuk melakukan pengawasan dan pengamanan kradit tersebut ditetukan dalam perjanjian kredit.

Pengawasa yang di lakukan oleh Bank Nagari Unit siteba, baik melalui laporanlaporan nasabah atau debitur kepada pihak bank,maupun peninjauan dari pihak bank secara langsung ke lokasi saha nasabah. Dari laporan dan tinjauan tersebut maka akan terlihat keadaan nasabah tersebut dsn penggunaan kredit dapat di ketahui oleh bank. Apabila bank menilai atau berpendapat bahwa keadaan nasabah dalam penggunaan kredit dapat mengancam kepentingan bank, maka bank akan melakukan tindakantindakan yang dianggap perlu dalam penanganan kredit.

Dalam melakukan pengawasan kredit sering timbul permasalahan yang dapat merugikan kepentingan kedua belah pihak, antara lain.

1. Laporan berkala mengenai aktifitas usaha dan keuangan tidak di sampakan oleh nasabah atau debiur tepat pada waktunya.

2. Laporan usaha nasabah penerima kredit jauh atau sulit dijangkau oleh petugas bank.

3. Jumlah personil bank yang bertugas untuk melakukan pengawasan dan penaganan kredit terbatas.

4. Nasabah debitur sering tidak melakukan kewajibnnya untuk menyampaikan laporan-laporansecara teratu kepada bank.

5. Nasabah debitur tidak jujur dan tidak terbuka untuk mengungkapkan atas masalah keuangan. 
6. Kurang aktifnya petugas bank untuk melakukan pemantauan atas penggunaan kredit dan kondisi perusahaan.

\section{SIMPULAN}

Berdasarkan uraian di atas yang telah di kemukakan, maka dapat di simpulkan sebagai berikut:

1. Bank Nagari Cabang Siteba merupakan salah satu bank yang memberikan pinjaman dalam bentuk kredit,yang bertujuannya adalah untuk membantu masyarakat khususnya di lingkungan siteba dan kota padang.

2. Dalam pelaksanaan pemberian kredit.bank nagari cabang selalu melakukan analisis kredit terhadap calon nasabah.serta melakukan peninjauan ke lokasi usaha debitur serta atas melakukan wawancara kepada debitur.

3. Untuk keamanan dari kredit yang di berikan kepada nasabah, Maka bank nagari memintak adanya jaminan kredit kepada pihak nasabah.

4. Penyelamatan dan penyelesaian kredit macet yang dilakukan bank nagari cabang siteba dapt dilakukan dengan berbagai cara,baik dengan cara kombinasi yaitu dengan cara memberi surat tunggakan dan surat peringatan terhadap debitur, memberikan keringanan pembayaran bunga dan tunggakaan pokok, serta mendesak debitur menjual agunan.

5. Penyebab utama dari kredit macet bisa saja dari kedua belah pihak,

a. Biasa saja dri pihak bank yang kurang tajam dalam menganalisis latar belakang calon nasabah, sehingga maksud dan tujuan serta pembayaran kembali kredit yang diberikan tidak dapat di ketahui secara jelas.

b. Dari pihak debitur, Rendahnya tingkat pendidikan nasabah yang menerima kredit, serta kurang adanya komunikasi yang terbuka antara nasabah dengan pihak bank ,dan hal inilah dasar atau penyebab kredit macet.

\section{DAFTAR PUSTAKA}

Alanshari, F., \& Marlius, D. (2018). Prosedur Pemberian Kredit KPR Pada PT. Bank Tabungan Negara (Persero) TBK Cabang Pembantu Bukittinggi. https://doi.org/10.31227/osf.io/rsfhc

Amelia, L., \& Marlius, D. (2018). Pengendalian Kredit Dalam Upaya Menciptakan Bank Yang Sehat Pada PT. Bank Pembangunan Daerah Sumatera Barat Cabang Utama Padang. https://doi.org/10.31227/osf.io/kpc64

Bank Indonesia. 1992. Undang -Undang. Nomor 7 Tahun 1992. Tentang Perbankan. Jakarta. Bank Indonesia.1992. Undang - Undang Nomor 10 Tahun 1998. Tentang Perbankan.Jakarta.

Dendawijaya Lukman. 2003. Manajemen Perbankan, EdisiKedua. Jakarta:Ghalia Indonesia. 
Hasibuan, Melayu. 2007. Dasar - Dasar Perbankan. Jakarta: PT Bumi Aksara. Ikatan Akuntansi Keuangan Indonesia. 2010. Standar Akuntansi Keuangan.

Shanjaya, A. R., \& Marlius, D. (2017). Peranan Laporan Keuangan Dalam Kebijaksanaan Pemberian Kredit Kepada Calon Nasabah Pada PT. BPR Batang Kapas. https://doi.org/10.31227/osf.io/uxmg6

Triandaru,Sigit dan Toko Budisantoso. 2008.Bank dan Lembaga Keuangan lain. Jakarta :Selemba Empat.

Yuliani.2007.'Hasibuan Efisiensi Operasional dengan kinerja profitabilitas pada sektor perbankan yang go public di bursa efek jakarta".jurnal manajemen dan bisnis sriwijaya. Vol.5 (10). 